\title{
YORUBA PHILOSOPHY OF EXISTENCE, IWA (CHARACTER) AND CONTEMPORARY SOCIO-POLITICAL ORDER
}

\author{
Olatunji A. Oyeshile \\ University of Ibadan, Nigeria
}

\begin{abstract}
What roles does Iwa [character in Yoruba belief] play in Yoruba philosophy of existence, and how can these roles help provide a solution to challenges of contemporary socio-political order, not only in Africa but also across the globe? Both are the daunting questions this paper sets out to examine. The foundation of Yoruba philosophy of existence is predicated mainly on the moral pivot called iwa. It is on iwa, which has both ontological and ethical etymologies that the meaning of life is based. Iwa regulates the social relations among people, and adherence to it within the Yoruba cultural matrix provides answers to complex questions of existence. It is submitted that the moral foundation of Yoruba philosophy of existence, as dictated by iwa, is a veritable basis for engendering normative principles for addressing problems in contemporary society as it harmonizes disparate interests for the common good, thereby reconciling the self with the other.
\end{abstract}

\section{INTRODUCTION}

In this paper, I want to share with you my thoughts on Iwa (character), which is the main pivot of Yoruba philosophy of existence and its implications for contemporary socio-political order, not only in Africa but across the globe. We know much as I do that morality (portrayed as Iwa in Yoruba culture) is very crucial to human development and survival. Likewise, the socio-political order is crucial. The search for a workable sociopolitical order has pre-occupied philosophers for ages; Plato, Aristotle, Rousseau, Kant, Locke, Hobbes, Mill, Marx, Hegel, Rawls, and many others come to mind. However, in the present circumstance, we cannot say all is well with contemporary society in terms of socio-political order. Many philosophers have also expressed the need for morality to be the guiding and guarding principle of socio-political activities. For instance, John Rawls' theory of justice is predicated on moral concepts such as justice, fairness, distributive justice, catering for the less well-off, and so forth (Rawls, 1971).

The foregoing indicates that there should be a synergy of morality and sociopolitical ideals in order to have a desirable socio-political order in any human society. What this means is that we cannot talk about sustainable development without a 
desirable social order. We cannot talk about a desirable social order without a desirable moral order (Oyeshile 2006a). Let us then describe some of the socio-political situations across the globe that lend credence to the imperative of morality. We may start by raising the question: What are some of the underlying factors that contributed to the social crisis in Africa, which is mired in civil wars, poverty, disease, illiteracy, child labor, corruption, political ineptitude, and economic disorientation? The economic, political, and religious spheres come to mind easily. Vices such as corruption, bad leadership, election rigging, fraud in public offices, inequitable distribution of national resources, and many others have been the albatross around the neck of African development (Oyeshile 2006a, 64).

As I have said, this crisis at the socio-political level spares no one, no group, no society, no country, and no civilization. Malgozarta Czarnocka $(2019,6)$ puts it this way, and I quote the lengthy passage to underscore my concern,

The causes initiating today's civilizational crisis are differently identified. However, it is commonly perceived that the crisis already spread over the entire human world - it has invaded all geographical regions and civilizational spheres - socio-political, economic, ecological, cultural, also the spheres of individual as well as collective human everyday life and personal existence. Our time of turmoil has generated a combustible mixture of threats: arrogance, irresponsibility, and the complete dereliction of duty by the ruling classes in many countries of the world, threats to security, global threats to national and international peace, threats to social order, increasing inequalities, the degradation of the natural environment.

Czarnocka opines further that fear and sense of insecurity have been our companions in spite of science and technological development. According to her $(2019,5-6)$,

In effect, fear, a sense of insecurity, and suffering are our common companions. However, our era has also produced many technological inventions which, for better or for worse, have changed human existence and the face of the earth. All the aspects of the present global condition, especially the causes of [the] crisis, need be urgently recognized and diagnosed - also on the highest level of generality in their foundations, that is, by philosophy. We may tentatively adopt - in a non-orthodox Marxian style - that the very fundaments of today's civilizational crisis lie in the political and social spheres.

Having given a vivid description of the kind of crisis in our epoch that has led to greater skepticism and elusive meaning in our quest for survival, my mission henceforth is to advance some solutions through Iwa (character) in Yoruba philosophy of existence. Moreover, as a philosopher, it is my task to engage these issues in such a way that we can make meaning of our existence. According to Charles Brown $(2019,15)$,

The traditional task of philosophy has always been to critique, clarify, and renew our shared ways of making sense of the world. This task is a 
continuation of a deeper and more fundamental project of humanity - the shared project of constructing a coherent and meaningful world. The roots of this project lie in our everyday, practical lives, in what Husserl called the lifeworld.

With this introduction capturing the background to the crisis of socio-political order, I shall engage in the following issues in the remaining part of the paper: the Yoruba philosophy of existence/worldview; Iwa (character) in Yoruba belief-system and application of Iwa to contemporary socio-political order.

\section{THE YORUBA WORLDVIEW/PHILOSOPHY OF EXISTENCE}

The Yoruba world view is tied to their philosophy of existence in which there is a general picture of the world and the place of man in it. More often than not, this worldview is subjected to philosophical evaluation to come to terms with man's flux of experience. In this section, we shall be looking at the Yoruba philosophy of existence which is inextricably tied to their worldview. According to Oladipo (2002, 155), "A world-view is not a product of fantasy. Rather, it is usually the outcome of a long process of reflection and speculation on the human condition." This then presupposes that the Yoruba world view is arrived at based on the reflection of the people on their experience of the world and which has led to one form of philosophy of existence or the other. Who are the Yoruba, and what constitutes their worldview or philosophy of existence?

The Yoruba are mainly settled in Oyo, Osun, Ondo, Ekiti, Ogun, and Lagos states in the Western part of Nigeria as well as in Kwara and Kogi states of Nigeria and some parts of Benin Republic. Some Yoruba are also found in parts of South America, such as Brazil. The Yoruba are distinguished by the fact that they speak Yoruba as their major language, but depending on the sub-tribes - Ijesha, Oyo, Ibadan, Ijebu, Ekiti, Egba, Yewa - would be able to communicate to other dialects as well.

One must note that just like any other people, the Yoruba have also been influenced by modernization arising from contact with other peoples. This contact has also had a corresponding effect on the religious, political, cultural, and economic activities of the Yoruba. On this line of thinking, Christianity and Islam have been embraced by the people alongside their traditional religions. So, it is plausible to say that people practice their religious beliefs simultaneously with foreign religions. The contact with people from other world cultures, which is popularly described as globalization, has had its effect on almost all the aspects of life, including social practice and naming.

The worldview of the Yoruba is made up of the Olodumare (Supreme Being), the divinities, such as Obatala, Orunmila, Sango, and Ogun, and the lesser spirits who could be both benevolent and malevolent. This hierarchy is followed by man. Man occupies a central place in the worldview of the Yoruba, but he is subject to the control of Olodumare and the divinities. The link between man and the spiritual entities is through Ori (inner head/personality spirit), which is amenable to the control of Olodumare and the divinities and the lesser spirits. The Ori is the carrier of human 
destiny, and this destiny can be good or bad. Whether good or bad, Iwa (character) is crucial in sustaining the good Ori or rectifying a bad one. Again, the susceptibility of Ori to modification has been a subject of debate between African philosophers who hold a fatalistic conception and a liberal conception of Ori. I have done extensive works on this (See O. A. Oyeshile, 2002, 2003a, 2003b, 2007a). At the bottom of the hierarchy, below man, we have lower animals, plants, and other non-living phenomena that are mainly subject to the control of man. Sometimes, man may not be able to control these lesser creatures and physical phenomena due to his limitations. Therefore, the typical Yoruba person employs both physical and non-physical means in dealing with and organizing his existence.

One needs to make some observations from this world view which is both 'thisworldly' and 'other-worldly.' One, it may be noted that it commits the average Yoruba to the control of the supernatural forces, thereby indirectly undermining his own physical strength especially given the fact that we live in a scientific and technological age. One may retort that this approach to the world is not peculiar to the Yoruba people. In fact, it is a common feature of all human cultures. Perhaps, the difference has to do with the level of emphasis among cultures. The Yoruba trace their source to the Supreme Being because they believe that human existence has both natural and supernatural sources, giving precedence to the latter and seen the former as being dependent on the supernatural.

Again, the Yoruba in spite of their belief in determinism - the scientific belief that every event has a cause, whether known or unknown - also move beyond this to attribute supernatural causes to an event, especially with regard to the destiny of man. This attitude, far from being unscientific, may be seen as a well-thought-out attitude to provide an explanation for all occurrences in nature, thereby making them pragmatic people.

Perhaps because of the above, Olusegun Oladipo reiterates the need for the modification of the Yoruba worldview. According to him, there is a need to move beyond the mythical worldview to a scientific one considering the challenges of today. In spite of this, Oladipo $(2002,163)$ believes that,

...it is clear that we require more than scientific and technological development in order to become a flourishing society in contemporary world. Indeed, for us to survive and flourish, there is an urgent need to create appropriate socio-ethical frameworks for harmonious and cooperative living.

Oladipo argues that the attainment of this harmonious and co-operative living will engender desirable social order and the needed ideals such as espoused by the traditional Yoruba worldview. According to Oladipo (2002, 163-164),

It is clear in this regard that traditional ideals of life - which in my view are universal human ideals anyway - are relevant to the promotion of social harmony in contemporary society. It would be difficult to deny, for instance, that such ideals of temperance, trustworthiness, truthfulness, compassion, and humility are some of the values we need to create a harmonious and co-operative society. 
As I have argued elsewhere, the Yoruba worldview is predicated on both the human and metaphysical agents, and this outlook provides for them a rational basis for approaching the daunting questions of existence. To buttress the above, I (2003a, 105 - 106) stated that,

What bears pointing out is that the Yoruba believes both in human and metaphysical agents concerning his existence. He believes in human agents because, as a rational being, he plays an important role in achieving certain ends. Hence, he works, behaves well in society, and associates with other human beings. In all these, he exercises his freedom. This also makes him primarily a determinist because he believes that certain causes are responsible for particular events. His freedom guides him in choosing the appropriate things to do. Furthermore, to the Yoruba individual, the metaphysical agents are of secondary importance and of last resort. He appeals to them - for example, to his ori (inner head/destiny) - when his human efforts fail or when he is overwhelmed by certain achievements. The ori is also of last resort because all human efforts, whether they lead to success or failure, are finally situated in this metaphysical agent. The reason for this is, perhaps, because he thinks existence transcends the physical world and the anticipation of death prompts him to think of an awesome force that directs his whole experience.

\section{IWA (CHARACTER) IN YORUBA BELIEF SYSTEM}

In every human society, morality plays an important role in regulating the conduct of individuals. Due to the importance attached to morality, humans have internalized the principles and values that would guide them in choosing the right course of action from time to time. Morality is therefore concerned with human conduct. Put differently, it is concerned with right and wrong actions, judgments, and beliefs about what is good or bad, without which the society, any human society, cannot develop. It is obvious then that morality is necessarily tied to human behavior or conduct because if this was not the case, there would be no need for praising or blaming people for their actions or training them to behave in a certain desirable way in society (Oladipo, 1987, 44-5).

Moral values constitute a very important aspect of any society. According to Gyekye $(1996,54)$, moral values are those forms or patterns of conduct that are considered most worthwhile and thus cherished by society. They constitute not only principles of behavior but also goals of social and individual action (Gyekye 1996, 54). The moral values in the traditional Yoruba belief system revolve around the concept of Iwa (character). In fact, there is a general consensus among the Yoruba that morality is summed up in the word Iwa which in ordinary English translation means character (Idowu 1962, 154).

Iwa (character) has so many derivatives, and it is often said: "that good character must be the dominant feature of a person's life" (Idowu, 1962, 154). From this conception of Iwa, it is common to hear such aphorism: Iwa or good character is a 
person's guard. The term Iwa sometimes has an ambivalent meaning because it is used in different senses to portray a person's character, whether good or bad. Wande Abimbola has shed light on different senses of the term (Abimbola 1975). We can at least distinguish about four or five senses in which the term is used, all of which are related. Etymologically, the word Iwa is formed from the root wa (to be, to exist) by the addition of the prefix $I$. therefore, the original meaning of Iwa can simply be interpreted as "the fact of being, living or existing" term (Abimbola, 1975, 393).

The second meaning of Iwa is character or moral behavior. This originates from the idiomatic usage of the original lexical meaning of Iwa. Taking this to be the case, Iwa construed as character is the essence of being (Abimbola 1975, 394). Simply put, $I w a$, in this sense, concerns the ethical aspects of man's life as distinguished from other areas of human endeavor such as economy and science.

In the third sense, the word Iwa is used to refer to either good or bad character (Abimbola 1975, 394). This sense of the statement can be demonstrated in such statements as,

\section{Iwa okunrin naa dara The man's character is good \\ Iwa okunrin naa ko dara The man's character is not good \\ Iwa omo naa ko dara The child's character is not good}

The fourth sense of the term, Iwa, is when it is used to refer to good character alone as in Obinrin naa ni iwa (the woman has good character). The fifth sense, which is derivative of the earlier senses of Iwa is when one talks about iwapele (gentle or good character) and iwabuburu (bad character).

The Yoruba have high regard for Iwa, and they see it as one of the aims of human existence. In order to achieve one's aim in life, which is the good life, one must embrace iwapele (ibid., 394-5). A person that refuses to exhibit good or gentle character is seen as a brute. The Yoruba say of such a person: Ki seniyan, nse lo fawo eniyan bora (He is not a human being, he merely assumes the skin of a human being).

A well-behaved person is described as $O$ seniyan (he acts the person). He can also be referred to as Omoluabi (one who behaves as a well-born or a morally upright person or a virtuous person). The foregoing has nothing to do with the denial or affirmation of the biological nature of a person. Rather the term eniyan (person) is used metaphorically to describe the moral nature of a person.

The importance of Iwa (character) is amply demonstrated in the odu corpus, according to Ogbe Egunda. (Idowu 1962,155). We are told the story of Orunmila, who was seeking success but was told this could only be possible if he married Iwa. He did and became very successful. The example of Orunmila made other people seek after Iwa, we are told, became the mother of many children as this Odu-Ifa shows (Idowu 1962, 155),

$\begin{array}{ll}\text { Ewa w'omo iwa beere o' } & \text { Come and behold the countless children of iwa, } \\ \text { Ewa w'omo iwa beere o' } & \text { Come and behold the countless children of iwa, } \\ \text { Iwa gbe dani } & \text { Iwa carries (children) in her arms } \\ \text { Iwapon seyi } n & \text { Iwa carries (children) on her back, } \\ \text { Ewa w'omo iwa berere. } & \text { Come and behold the countless children of iwa }\end{array}$




\section{WHY MUST ONE BE MORAL IN YORUBA SOCIETY?}

Central to the observance of any moral norm in any society is the question: Why should I be moral? The question can be reframed in other ways to mean: Why should I obey moral norms? Why should people obey moral norms? An answer to any of these questions can equally serve as an answer to other questions. Many theories, especially in Western societies, have attempted to address these questions. According to Frankena $(1995,14)$, these related questions involve asking for,

(1.) The motive for doing what is morally right, (2.) a justification for doing what is morally right, (3) motivation for adopting the moral point of view and otherwise subscribing to the moral institution of life or (4.) a justification for morality and the moral point of view.

Some of the answers provided for our questions may include some or all of the following: That we are moral because God or the gods commanded it; that we are moral because our conscience cannot wish or will otherwise; and that we are moral because it is the agent's self-interest to be so. All these factors have been taken as the grounds for moral obligation. However, we shall show that in traditional Yoruba society, like many other societies, the ground for a moral obligation is based primarily on human wellbeing, which incorporates the well-being of the society and the individual himself.

It is necessary to be moral in order to have a satisfactory human life; otherwise, we shall all be worse-off. If we pursue this argument to its limits, it would be shown that being moral is to the advantage of the agent. In other words, the non-moral reason for being moral is the advantage that accrues to the agent himself, which some have called self-interest. Since the rationale for being moral is based on human well-being, prudential and expeditious actions that ensure that the individual's self-interest is guaranteed cannot be over-emphasized.

Our attempt, therefore, shall be to show how other grounds of moral obligation, in particular the religious ground, support the main factor, which is human well-being. In other words, these other factors are only secondary and do not provide an adequate ground for why one should be moral.

Let us start our analysis with the question: Why must a person have iwa (good character). Going by the religious argument, one is moral because Olodumare (the Supreme Being) has commanded it. Furthermore, by having iwa, man can be free from the authoritarian and hierarchical structure of the universe. Iwa also ensures that a man's life is guided by some principles that enable him to avoid collision with supernatural forces and fellow men.

We shall see that the moral person in the Yoruba universe embraces iwa primarily to have good existence, such as is rational to conceive that nature intends that he should have. He, therefore, enjoys relative freedom from the oppression of nature and the tyranny of the flesh (Oke 1988, 95). The constant reference a Yoruba individual makes to God in moral matters becomes necessary when empirical solutions to his problems fail. For instance, in the case of theft that cannot be unraveled through the empirical method, Olodumare is called to intervene. And the fact that Yoruba's moral reasoning involves the supernatural does not mean that it leads to transcendental 
morality. On the contrary, the concern for the natural existence of each person occupies a central place in their moral universe (Oke 1988, 96). For example, any person that goes against the moral rules is made to face appropriate moral sanctions.

We can say that people obey moral laws to enjoy the benefits of morality on the one hand and to avoid sanctions that accompany the violation of such moral rules, on the other hand. In talking about benefits, the individual tries to be prudent in his actions. He also takes actions on an expeditious basis, depending on the situation he finds himself in. All these points to the fact that human well-being, in the form of individual interest and societal interest, constitutes the main rationale for being moral.

A look at the various interpretations and application of morality in the traditional Yoruba belief system will buttress our analysis. The first interpretation is that morality is not just a means to harmony with the universe but also an end in itself. This means that it is a good worth pursuing itself. Secondly, it is believed that without morality or at least morally good persons, the world would be a difficult place to live in. The third is that being moral has its own burden, but the burden should not discourage a person from a moral life since morality is the very essence and value of life, and fourthly, the Yoruba are persuaded to be moral because of posterity. It is believed that neither good nor bad conduct shall perish or be forgotten (Oke 1988, 96).

Close scrutiny of all these interpretations of morality in the traditional Yoruba universe only points to one factor - human-wellbeing. The claim that morality is a good worth pursuing on its own would, on closer analysis, be seen to yield certain benefits. The benefit will accrue to one who is moral. Furthermore, the claim that morality is necessary because of posterity can also be seen as a claim that has human well-being as a focus. For example, a person who died leaving behind good deeds had already established a good environment for his offsprings. On the contrary, if no one stands to gain from the good deeds of a deceased person, many people while alive would restrict their actions to what is of immediate benefit to their present state. Therefore, whether one is guided by considerations of what one gains in physical existence or in non-physical existence, the utmost factor is the well-being of the agent in particular and the society in general.

Another close look at the way we speak about morality in traditional societies would reveal a pre-occupation with human welfare (Wiredu 1980, 6). For instance, what is morally good should be what befits a human being, what promotes human dignity, and what brings joy to man and his community. On the contrary, what brings misery, disgrace and misfortune are morally bad. While no one can contest the claim that the Supreme Being hates immoral conduct, it is the case that God approves something (conduct or action) if such a thing is good in the first place (Oke 1988, 96).

Even though we cannot down-play the role of the supernatural being when considering the rationale for being moral in the traditional Yoruba universe, the individual's moral observance is dictated by prudence and expediency because his main goal is human well-being. Even when we consider the moral injunctions from the Supreme Being, we see that these injunctions are towards human well-being. Man as a rational being always has in focus what he stands to gain by embarking on any course of action, be it moral or otherwise.

How does our understanding of the rationale for being moral help to address the sense of insecurity in the contemporary world? If the primary rationale for being moral is human well-being, as the Yoruba example has shown, then the well-being of the 
world community is ensured based on the well-being of every member of the human or world community. And because the individual is a social being, any decision by him, which is immoral, would affect the well-being of other members of the society and subsequently retard human development, peace and security. Therefore, it is the duty of every community to ensure that individuals imbibe moral virtues through education, communal living, reward, and sanctions. Though it is in the individual's self-interest to be moral, this self-interest can only be guaranteed from the perspective of the well-being of all.

Let us note that irrespective of our approach to moral issues, human well-being should be our focus. A safe world will be one that is pre-occupied with ensuring the well-being of individuals, groups, institutions, communities, nations, and races. We cannot bargain less than human well-being, irrespective of our differences if life is to continue and be meaningful on our planet.

In the Yoruba belief system, moral values are the basic elements that make up the moral framework. They can be referred to as moral norms, defining elements of morality, moral components, moral constituents, and moral practices. The moral values are intertwined with the mores of the people in many traditional African cultures. Some of the moral values in Yoruba traditional society include hospitality (isalejo), opposition to selfishness (imotaraeninikan), avoidance of wickedness (iwabuburu), truth and rectitude (ododo or otito and otito inu), condemnation of stealing (ole), keeping covenant (imule), opposition to hypocrisy (agabagebe), cooperation (ifowosowopo) and tolerance (amumora).

From the above, one can say that morality in Yoruba society is communally centered in the sense that when promoting his own well-being, the individual also promotes the well-being of members of his community. This tendency has generated debates concerning individual autonomy within the Yoruba communal moral universe as well as the issue concerning the radical communitarian thesis of person in African philosophy (Gyekye 1992; Mbiti 1969; Menkiti 1984; Oyeshile 2006b).

But it is imperative to point out some issues before engaging in how iwa (character) and omoluwabi (person who promotes character/a well-behaved person) can contribute to engendering and sustenance of normative or desirable social order in the contemporary world.

The dictates of iwa (character) within the traditional Yoruba society make an individual's freedom a relative one, relative to the survival of the individual in the Yoruba community. It is a means to the good life of man and his community. In exercising his autonomy, the primary aim is for the individual to be a fully accomplished individual who, at the end of the day, achieves happiness in anticipation of a blissful life after death (Oyeshile 2007b, 292). The following aphorisms underscore the relative freedom of the Yoruba individual:

1. Ti eye ko ba ni feye niron, oju orun teye fo lai fara kan-ra [If birds do not want to create inconvenience for themselves, the sky is large enough for every bird to fly].

2. Enikan ki je ki ile fe [One person does not consume everything and expects expansion or progress of the land].

3. Owo die die ni ara nfe [The body/person deserves some respect]. 
4. Owo ki ndowo lorun [One person's business endeavor does not create inconvenience for another person's business endeavor]

5. Ti a ba soko soja, ara ile eni ni nba [if we throw a stone in the market, it is the person's of our household that it hits].

Explanation of the aphorisms within the Yoruba moral universe (Oyeshile 2007b, 283-4). The first aphorism establishes that all birds have their freedom to fly, but this freedom is not absolute. Rather, it is relative because other birds also have to fly. Nature has made the sky wide enough to accommodate other birds such that any bird that prevents the other from flying is merely paving the way for quarrel. The aphorism underscores the need for individuals in the Yoruba community to recognize the relative nature of their freedom and the need to recognize the freedom of others.

The second aphorism establishes that the individual's freedom does not give him the license to consume everything in an unlimited fashion, as this would be inimical to the growth and progress of the community. For an individual to arrogate to himself the freedom and power to consume everything meant for a group would be self-contradictory and against the individual's self-interest since he would be denied certain benefits if other individuals were to do the same.

Our third aphorism enjoins the individual to accord some respect to other individuals since they are as important as himself. Hence, he can only enjoy his freedom if he concedes the same to other people by acknowledging their dignity. The fourth aphorism is often illustrated through business enterprise. An individual's freedom to aspire to be one thing or the other should not serve as an obstacle to another individual in actualizing his potentials. The fifth aphorism lends a moral dimension to relative freedom given the fact that it is not only wrong to use your freedom as you please, you must also consider the consequences of exercising this freedom. It is believed by the Yoruba that a person may be hurting his own relations indirectly, which is also a harm to oneself by the indiscriminate use of freedom, especially in negative acts such as trying to create a crisis in social relations.

It is within this communal moral universe that the Yoruba individual exercises his freedom, autonomy, right, and authenticity not in absolute terms but in relative terms as part of the community as aptly expressed by Mbiti that "I am because we are, and since we are therefore I am" (Mbiti 1969, 108).

\section{APPROPRIATING IWA TO ENGENDER SOCIO-POLITICAL ORDER IN CONTEMPORARY SOCIETY}

When I talk about contemporary society, I am talking about human society. The globalization trend deciphered from its various dimensions - economic, political, information/communication, religious and scientific and technological - has made all cultures to be accessible by others and therefore affective such that to repeat the popular dictum - the world is now a global village linked together by the worldwide web. Values across cultures have become common, while identity is no longer as sacrosanct as it used to be centuries ago. Our century is a century of commoners and commonness. 
Again, let us note that the main thrust of moral education in Yoruba culture is to make the individual an omoluwabi (a person with good character or the reflector of $i w a)$. Therefore, an omoluwabi presupposes that one must be of good character in all aspects of human endeavor. As Awoniyi noted, the virtues of good character such as respect for old age, loyalty to one's parents and local traditions, honesty in public and private dealings, devotion to duty, readiness to assist the needy and the infirm, sympathy, courage, and kindness are virtues that tend to stabilize the community as strict adherence to them helps to make the individual a useful member of the society (Awoniyi 1975, 365). In a situation where the individuals manifest $i w a$, the level of social disorder is highly reduced. The implication of the foregoing is that since social relations actually matter in determining the development of a community, any community that upholds these moral values will experience development in qualitative and quantitative terms.

Before relating $i w a$ and its elements to socio-political order in contemporary society, let us, for the sake of emphasis, reiterate the crisis of socio-political disorder in contemporary global relations as aptly captured by Ademola Dasylva. According to $\operatorname{him}(2016,67)$,

The challenge of modernity is characterized by wars, diseases, and poverty, as well as poor governance, especially in developing nations. Other problems include man's inhumanity to man, greed, corruption, political intrigues, and in Nigeria and perhaps some other African countries, ritual murder, arson, kidnapping, climatic changes as a result of environmental degradation and general pollution, etc.; this scenario summarizes the reality of the so-called modern world.

I agree with Dasylva's submission on the description and predicament of humans in the contemporary world, especially at the social and political level. In fact, no corner of the world, no matter how remote, is exonerated or immune from these problems. These growing negative tendencies continually call into question the role of philosophers in providing order to the chaos that defines our daily existence. The philosopher, according to Plato, has the onerous task of bringing men to reality, truth, justice, and the good life. This search for a stable socio-political order can be engendered through a critical application of traditional pristine values such as iwa (character) in the Yoruba worldview.

Therefore, in what ways can we use iwa (character) and its possessor, omoluwabi, to engender socio-political order in contemporary society? I will appropriate this task by analyzing some defining elements of morality in Yoruba culture, which I believe, if internalized, adopted, and reflected in social relations, can be a veritable basis for resolving the problem of the social and political order in contemporary society. It should be noted that major problems in contemporary society revolve around our inability to come to terms with these defining elements in Yoruba culture. It is very clear that hospitality, opposition to selfishness, kindness, opposition to wickedness, truth, and rectitude, the keeping of covenant have gradually declined in contemporary society, while wickedness, stealing, oppression in international relations have become the order of the day. Let us then examine these defining elements and draw relevant inferences. 
Hospitality is an important component of good character in Yoruba culture (Idowu, 1962, 157). It is believed that the Yoruba people are generally hospitable or caring to other people, especially strangers on a journey. Except for foreign influence and the sophistication of contemporary society, the traditional Yoruba never thought twice about accommodating strangers in his home. They also provide food for such strangers at their own expense. They believe that this is right because one can be in the situation of a stranger on a future date. The willingness to take good care of a stranger will always be supported by the popular saying in Yoruba that: iyan ogun odun a ma jo ni lowo. [A yam meal of twenty years can still be hot to touch]. The essence of this popular saying is that "an act of hospitality can have its reward twenty years later."

Another defining element of Yoruba morality is opposition to selfishness. A person is selfish if he thinks about his own welfare all the time and does not engage in any act unless he would derive some benefits from such an act. The Yoruba hold a selfish person in contempt and do not bother to render him assistance when he is in difficulty. A selfish act can be manifested in various ways. For example, there is the saying that, Agba toje a-je wehin a ru 'gba e de le. [An elder who eats his food without thinking of others will carry his load home himself, which means no one will help him]. There is also the saying that. Gba fun Gbada nile, ni gba fun Gbada l'oko. [Give this to Gbada in town will necessitate Gbada in town to send something to Gbada in the village].

There is Odu called Irete-meji, which tells a story warning people not to be selfish (Idowu 1962, 157). We are told that Orunmila was once given to selfishness which made him contemptible to his neighbors in Are. One day Orunmila fell into a deep pit and called on the passers-by from Are to pull him up, but they refused to help him; instead, they told him to keep enjoying the consequence of his selfishness, as shown in the following lines (Idowu 1962, 158-159),

Orunmila shouted:

Okunrin Are:

Obinrin Are;

A-t'oni m'oni

A-t'ana m'ana,

Erungbon ijeta;

Alde mbe ninu ofin,

O nyi gbiri.

They replied:

Igbati o nje apa aja

Ta l'o ke si

Igbati o nje ige agbo,

Ta l'ope

Igbati o nf'apa obuko wa ko mu, When you were having corn-porridge with a he-goat's arm

Talo ri o?

Nje Okunrin Are!
Men of Are!

Women of Are!

It has been all day today,

It has been since yesterday,

It is now practically the third,

The crowned one has been in the pit,

Rolling about.
When you were feeding on dog's arms

Whom did you invite?

Whom did you call?
When you were eating ram's breast,

Who saw you?

Now "men of Are! 


Obinrin Are!
A-t'oni m'oni
A-t'ana m'ana,
Erugbon ijeta;
Jeki Alade joko s'inu ofin
K'oma yi gbiri.

Obinrin Are!

Erugbon ijeta;

K’oma yi gbiri.

\author{
Women of Are! \\ It has been all day today \\ It has been since yesterday, \\ It is now practically the third day; \\ Let the crowned one remain in the pit, \\ Rolling about.
}

Kindness literally translated ore is another component of good character. Though kindness is related to hospitality, the latter is mainly towards a stranger. However, kindness incorporates hospitality. The Yoruba believe that a kind person (olore) is always blessed by God and protected from any kind of mishap. There are a lot of Yoruba sayings that enjoin a person to be kind. For instance (Idowu 1962, 159),
Igba olore ki fo,
The calabash of the kind breaks not,
Awo olore ki faya
The dish of the kind splits not,
T'owo tomo ni'ya le olore
It is both money and children that flow into the house of the kind.

The import of the above saying is that the kind person is always richly blessed both in terms of human and material things; furthermore, he is always protected from the travails of life. As part of their defining moral components, the Yoruba not only frown at wickedness but condemn it in its totality. They believe that the law of retributive justice will always catch up with the wicked person and his offsprings. The condemnation of wickedness features prominently in the day-to-day utterances of the Yoruba. Such utterances include the following:

Eniti o ba d'eru ni eruto [The ashes blow after the person who throws them]; Eniti o ba gbi ebu ika, ori omo re ni yi o hu le' [He who sows the seed of wickedness, it is on his children's head that it will grow].

All the above suggest that the effect of wickedness ultimately falls back on the wicked person and his children. There are various myths and stories in Yoruba culture which suggest that wickedness should not be embraced in any form. Truth and rectitude are also among the prominent moral elements in Yoruba culture. These two terms are often used interchangeably. Truth translates ododo or otito, while rectitude means otito inu. The Yoruba contrasts these moral elements, which they regard as virtues, with other vices such as lie (eke) and covenant-breaking (didale). The Yoruba strive to embrace truthfulness and rectitude because they believe that these virtues help in achieving success in life. Furthermore, they also believe that if one is truthful and upright, he would have unfailing support and blessing of the divinities as can be discerned in the popular song from an Odu called Eturupon meji (Idowu 1962, 161),

$\begin{array}{ll}\text { S'otito; se rere, } & \text { Be truthful, do good; } \\ \text { S'otito o, se rere; } & \text { Be truthful, do good; } \\ \text { Eni s'otito } & \text { It is the truthful } \\ \text { N'imale igbe. } & \text { That the divinities support. }\end{array}$


To show further the importance of truthfulness and rectitude, a story that has it that the truth, liar, and covenant breaker went on a journey to a foreign land in which it was the truth that became successful. Truth is represented by Orunmila, who claimed he was successful because he was faithful and honest with the people in the foreign land. This is expressed by the oracle (Adewale, 1986, 63) thus,

$\begin{array}{ll}\begin{array}{l}\text { Eke re 'bi, ko de } \\ \text { Odale re dale, } k \text { obo }\end{array} & \begin{array}{l}\text { Liar went on a journey and never returned } \\ \text { Covenant-breaker went to a foreign country and } \\ \text { never came back }\end{array} \\ \begin{array}{ll}\text { Od'ifa f'otito inu } \\ \text { T'oni aje se ku ju 'ro lo. }\end{array} & \begin{array}{l}\text { Who said that not eating up one's store is better than } \\ \text { lying }\end{array}\end{array}$

Stealing in any form is condemned in the traditional Yoruba society. In the old days, stiff penalties were meted out to thieves. These punishments could range from strokes of the cane, being banished to another town, being fined some items, that could include money, being ostracized for some time to being killed if the stealing is such as injured others' life. Sometimes when a thief escapes being seen or caught, the Yoruba resort to Olodumare, believing that the latter will dispense justice. This can be clearly gleaned from such sayings as'

A-mokun sole, bi oju oba aiye orii, t'oba orun nwo o. [He who steals under concealment (secretly), even though the eyes of the earthly ruler do not see him, those of the king in heaven are looking at him].

One should also note that before the so-called modernization of Yoruba society, the society had lesser cases of theft. In some instances, items were displayed freely on the road or outside a compound. Those who needed such items left their money and took goods commensurate to their money. Even a hungry traveler could enter a farm and take only enough fruits or food items such as cocoyam to help him overcome his hunger.

Another moral component of Yoruba morality is keeping covenant or, put negatively, non-breaking of the covenant. Covenant (imule) is held sacred among the Yoruba. False-hood always accompanies covenant breaking (idale) because it is believed that it is only a person who is given to falsehood that can always deceive and betray others. The covenant breaker is called odale, and it is believed that such a person can never prosper. Covenant keeping involves a number of other ethical practices such as loyalty among friends, loyalty between the husband and wife, faithfulness and loyalty among relations, and not being a tale-bearer or somebody who cannot keep secrets. There are several sayings among the Yoruba showing the sanctity of covenant. For example:

Eni ti o ba da'le, a ba 'le lo. [The covenant-breaker will disappear with the earth or will be carried away by the earth].

Covenant, as it exists in various ways, can be broken in several ways. These could be through tale-bearing or telling lies against others, through stealing, through 
betrayal in a business venture, and even though adultery when a man seduces another man's wife, notwithstanding the status of the people involved in the act. For instance, there is a story of Eturupon-Okanran from Odu corpus that tells how an assistant of Orunmila seduced the wife of the latter and kept the matter secret but had to make confession when he became very ill (Idowu 1962, 162). Thus, we have the following saying (Idowu 1962, 163-164),
Eke 'o sunwon ara eni
Falsehood is not right for one,
o-da-le 'o sunwon ara enia;
Covenant-breaking is good for no man;
$B$ 'omode ba nyo 'le da,
If the young surreptitiously breaks covenant,
Ohun abe - nu a ma yo won se,
$O$ da fun ajubona
Ti o lo nfe obinrin oluwo.
Ills surreptitious will befall them
So declared the oracle for the ajubona
Who went and seduced the wife of oluwo.

Closely related to the breaking of covenant is hypocrisy. The Yoruba regard hypocrisy, known as agabagebe. The literal interpretation is somebody who moves in a zigzag manner, and this is further rooted in the fact that a hypocrite is somebody who tries to climb a ladder and a mound simultaneously ((Idowu 1962,164). What is important is that a hypocrite has an unpredictable moral character, and such persons are never taken by their words or trusted in any important matter because such matters are bound to end up in betrayal. The Yoruba also believe that Olodumare forbids hypocrisy and that whatever the situation is, a person must be firm or noted for a particular principle or position. This is shown in Oyeku-meji (Idowu 1962,164) that,
Eniti ti o ba nsakin
He who is brave,
K'oma m'ohun s'ojo;
Eni ti o ba n s'ojo
Let him not declare himself cowardly;
K'oma m'ohun s'akin,
He who is cowardly
Let him not declare himself brave.

A look at some of the defining elements of Yoruba morality shows that it moves from the standpoint of the community to the individual's standpoint. In other words, it is "community conscious" in the sense that an individual is regarded as a person of good character (iwa rere) if his actions are such that engender good for the community first and then to himself. Perhaps, this is the reason why it has been argued that there are elements of the Golden rule, whose main maxim is "Do unto others as you would want that they should do unto you, in the Yoruba moral system (Idowu 1962, 166). This belief is supported by the claim that:
Bi a ba se 'gi nigbo,
Whenever we fell a tree in the forest,
$K$ 'a f'oran ro ara eni wo
let us put ourselves in the position of the tree being felled.

The above claim is further buttressed by the saying (Idowu 1962, 166),
"Bi o ti ndun omo eku
As sensitive to pain as are rat's little ones
Be na l'o ndun omo eye"
so sensitive to pain are bird's little ones 
The above claims show that the individual in traditional Yoruba society is moral as long as his actions are not taken from a selfish perspective. Granted that this is the case, we can still make some general observations about the defining elements of Yoruba morality. First, it can hardly be disputed that almost all the moral norms in Yoruba culture are interrelated. In other words, they form a family circle. There are those construed as positive moral norms, which the individuals are supposed to imbibe and practice. These include truthfulness, rectitude, honesty, the keeping of covenants, and good neighborliness. There are also negative moral prohibitions such as stealing, hypocrisy, tale-bearing, and covenant-breaking. Whenever one keeps to any of the positive injunctions such as being truthful, he will be deemed to possess other virtues such as honesty and good-neighborliness. Similarly, when one is a thief, which is forbidden, the Yoruba would not hesitate to label that person a liar.

From the discussion above, it is clear that ethical considerations provide the basis for a meaningful relationship at all levels of human existence. We should be moral in dealing with others. Other people, ethnic groups, and nationalities are not to be treated as mere means to the satisfaction of our own ends but as a kingdom of ends in themselves. Kant has advanced the thesis of the Categorical Imperative with the injunction that we should act on the maxim through which we can at the same time will that it should become a Universal law (Kant 1980, 425) The Yoruba worldview, from which Iwa is derived, is replete with injunctions that stress the need for ethical considerations of others. For instance, the concepts of ajobi (consanguinity) and ajogbe (co-residentship) emphasize what we share together both as to blood relations and nonblood relations. The point of emphasis is that the Yoruba communal universe encourages the need for interdependence and co-existence, which guides not only social and political behavior but also engenders socio-political order that is desirable for human flourishing.

\section{CONCLUSION}

The fact that every culture makes one contribution or the other to global order provided the impetus for this paper's focus. My paper has dealt with how iwa (character), a major element in Yoruba philosophy of existence, can contribute effectively to the social and political order in the contemporary period. This is based on the fact that iwa advocates co-operative existence in which the individual's interests are reconciled with the interests of others and the community as a whole. The defining elements of iwa amply showcase a communally oriented philosophy without sacrificing an individual's freedom. This freedom of the individual is exercised in relative, mitigated, and moderated form and not in absolute terms since the individual is a social being who has to co-exist with others.

I want to note that iwa (character), though a necessary condition for sociopolitical order, is not a sufficient condition for socio-political order. This is because morality itself has to be supported by social policies, law, social structures, welfarist government, and a viable economic system to be effective. For instance, no matter how morally upright, a hungry man who is about to die of hunger is likely to steal if nobody or society comes to his or her aid. Ethnic oppression may discourage co-operation among disparate ethnic groups as we have in Africa and some parts of the world. 
Therefore, it is imperative to have the right social policies within and among states in order for morality to flourish so that we do not relapse into the Hobbesian stare where "life is solitary, poor, nasty, brutish and short."

I want to end this paper with the saying 'iwa l'ewa, toju iwa re o' [character is beauty, guide your character].

\section{NOTE}

This paper was presented at the Institute of Philosophy, University of Leiden, The Netherlands, on Thursday, 5 September 2019, to mark the opening of the 2019/2020 Academic year. Many thanks are due to Prof. J.W. McAllister, the Academic Director of the Institute, and other members of staff.

\section{REFERENCES}

Abimbola, Wande. 1975. Iwapele: The concept of good character in Ifa literary corpus. In Yoruba Oral Tradition. Edited by Wande Abimbola. Ibadan: Ibadan University Press, 389 - 420.

Adewale, Samuel. A. 1986. Ethics in Ifa. In Religion and Ethics in Nigeria. Edited by Samuel. O. Abogunrin. Ibadan: Daystar, 60 - 71.

Awoniyi, Timothy. A. 1975. Omoluwabi: The fundamental basis of Yoruba traditional education. In Yoruba Oral Tradition. Edited by Wande Abimbola. Ibadan: Ibadan University Press, 358 - 388.

Brown, Charles. 2019. Revisiting nihilism since 1989. Keynote Address to the 12th World Congress of the International Society for Universal Dialogue, Lima, Peru. Dialogue and Universalism 29(1), 9 - 16.

Czarnocka, Małgorzata. 2019. Editorial. Dialogue and Universalism, 29(1), 5 - 7.

Dasylva, Ademola. 2016. Glocalization of Yoruba Omoluwabi ideology. Yoruba Studies Review, 1(1), 65 - 84.

Frankena, William. K. 1995. Ethics. NewDelhi: Prentice-Hall of India Private Ltd.

Gyekye, Kwame. 1992. Person and community in African thought. In Person and Community. Edited by Kwasi Wiredu \& Kwame Gyekye. Washington: The Council for Research in Values and Philosophy, 101 - 102.

Gyekye, Kwame. 1996. African cultural values. Accra: Sankofa Publishing Company. Idowu, E. Bolaji. 1962. Olodumare: God in Yoruba belief. London: Longman Publishers.

Kant, Immanuel. 1980. The Categorical Imperative. In Enduring Questions: Main Problems of Philosophy. Edited by Melvin Rader. New York: Holt, Rinehart and Winston, 417 - 432.

Mbiti, John. S. 1969. African religions and philosophy. London: Heinemann.

Menkiti, Ifeanyi. 1984. Person and community in African traditional thought. In African Philosophy: An Introduction. Cited by Richard. A. Wright. Lanham: University Press of America, 171 - 181.

Oke, Moses. 1988. Self-Interest as the ground of moral obligation. Second Order, 1(2), 
$79-103$.

Oladipo, Olusegun. 1987. Morality in Yoruba thought: A philosophical analysis. Quest, 1(2), 42 - 51.

Oladipo, Olusegun. 2002. Rethinking Yoruba worldview and ideals of life. In The Third Way in African Philosophy: Essays in Honour of Kwasi Wiredu. Edited by Olusegun Oladipo. Ibadan: Hope Publications, 155 - 167.

Oyeshile, Olatunji. A. 2002. Towards an African concept of a person: Person in Yoruba, Akan and Igbo thoughts. Orita: Ibadan Journal of Religious Studies, 1 \& 2, $104-114$.

Oyeshile, Olatunji. A. 2003a. Predestination and freewill in the Yoruba concept of a person: Contradictions and paradoxes. Philosophy, Culture and Traditions, 3, 99 - 107.

Oyeshile, Olatunji. A. 2003b. Traditional Yoruba social-ethical values and governance in modern Africa. Philosophia Africana, 6(2), 81 - 88.

Oyeshile, Olatunji. 2006a. Morality and social order in contemporary Africa. Prajna Vihara: Journal of Philosophy and Religion, 7(1), 62 - 74.

Oyeshile, Olatunji. A. 2006b. The individual-Community relationship as an issue in social and political philosophy. In Core Issues in African Philosophy. Edited by Olusegun Oladipo. Ibadan: Hope Publications, 102 - 119.

Oyeshile, Olatunji. A. 2007a. Religious and secular origins of morality within the Yoruba framework: Implications for man and society. Prajna Vihara: Journal of Philosophy and Religion, 8(1), 82 - 99.

Oyeshile, Olatunji. A. 2007b. Resolving the tension between corporate existence and the individual's freedom in African communal society: The Yoruba example. Ultimate Reality and Meaning, 30(4), 278 - 300.

Rawls, John. 1971. A theory of justice. London: Oxford University Press.

Wiredu, Kwasi. 1980. Philosophy and an African culture. Cambridge: Cambridge University Press. 